УДК 69.01

DOI $10.21661 / \mathrm{r}-118031$

\title{
И.Н. Залесов
}

\section{РОЛЬ АРХИТЕКТУРНОГО ПОЛНОГО ОРДЕРА В АРХИТЕКТУРЕ}

Аннотация: данная статья посвящена исследованию роли архитектурного полного ордера в архитектуре. Рассматриваются основные виды данного ордера, представлены его составляющие части. Изучается связь существования архитектурного полного ордера с современным миром архитектуры и строительства, его влияние на формирование современных тенденций.

Ключевые слова: колонна, архитектурный полный ордер, пьедестал, антаблемент, база, дорический ордер, ионический ордер, корфинский ордер.

\section{I.N. Zalesov}

\section{THE ROLE OF ARCHITECTURAL FULL ORDER IN ARCHITECTURE}

Abstract: this article is about the role of full architecture order in the field of architecture. The main types of this order as well as its basic components have been studied. The author also tries to find out the influence of this order on the development and modern tendencies in the modern world of architecture and construction.

Keywords: column, full architecture order, pedestal, enablement, base, Dorian order, Ionic order, Corinthian order.

В современном мире активной темой в строительстве становится архитектурный ордер. Использование ордера как символа и переложение его на современный строительный язык привели к созданию нестандартных формообразований в архитектуре. Можно наблюдать, как развивается постмодернистское направление в архитектуре, основной задачей которого является создание образности и оригинальности. Внедряется декорирование стен, барельефы, росписи, которые часто заимствуются из исторических архитектурных традиций. Во главе угла поставлена эстетика, для создания которой архитекторы-постмодернисты используют исторические стили, вплоть до принципов построения композиции. 
На самом деле, классические архитектурные ордера - это образец правдивости и ясности, бесспорный пример гармоничности общих форм и всех частей, единства архитектурно-эстетических конструктивно-тектонических элементов сооружений, как в экстерьере, так и в интерьере. Не удивительно, что к ним не угасает интерес, как со стороны профессионалов, так и простых обывателей.

Архитектурные ордера имеют богатую историю, неизменно проходят через всю историю архитектуры, и в каждой эпохе они приобретают свою специфику и неповторимые черты. Тем не менее, нужно понимать, что в классической ордерной архитектуре заложены основные принципы архитектурного искусства, которые не потеряли своей актуальности и в современном мире. В ордерной архитектуре сосредоточены многие специфические закономерности и выразительные средства архитектурной композиции: контраст, ритм, нюанс, пропорции, и т. д.

Архитектурный ордер - это определённый порядок архитектурных форм, в котором выделяются несущие и несомые части. Порядок, в котором устанавливаются определённые закономерные связи между частями здания, и эти связи направлены на выражение художественного образа сооружения; сумма правил, которыми определяются пропорции и формы сооружения [1, с. 6].

Ордер встречается ещё в архитектуре древней Персии, Египта и Ассиро-Вавилонии. Однако ордер, как архитектурная строительная система, с точными правилами построения и оформления получил высшее развитие в древней Греции, и именно греческие архитекторы установили приемы взаимосвязи и определенный порядок расположения основных элементов ордерной конструкции.

В более поздние времена римский архитектор Витрувий изучил греческие ордера и ввел слово ordo, обозначающее ряд, строй, порядок, систему расположения частей стоечно-балочной конструкции архитектурного сооружения. При этом распределение и взаимодействие несомых и несущих частей - тектоника сооружения получили художественно-образное выражение в классических форmax.

Теория ордеров получила свое окончательное завершение в эпоху Возрождения в Италии в течении XV и XVI веков. В частности в это время были созданы 
труды по архитектуре, которые стадии основой для изучений теории ордеров архитекторами всех времен: «Правило пяти ордеров архитектуры», автором которой является итальянский архитектор и теоретик Джакомо Бароцци да Виньола (1562 г.) и «Четыре книги об архитектуре» итальянского архитектора Палладио (1570 г.).

Рассмотрим кратко составные части архитектурного полного ордера. В первую очередь, следует отметить, что он состоит из трёх частей: пьедесталанижней части, колоннь - средней части и антаблемента - верхней части. Неполный ордер не имеет пьедестала.

Пьедестал в свою очередь состоит из других трёх частей: базы, тела пьедестала, или стула и карниза. База - это нижняя часть пьедестала в виде высокой полки или плиты, на которой расположены гуськи, валики, полочки и другие архитектурные обломы. Обломами называют архитектурные детали, отличающиеся по очертаниям. Они бывают прямолинейными и криволинейными. На базе расположено тело пьедестала (стул). Вверху пьедестал увенчан карнизом простой или сложной формы.

Колонна покоится на пьедестале и поддерживает антаблемент. Колонна состоит из трёх частей: базы, стержня (тела) самой колонны и капители. База нижняя часть колонны, состоящая обычно из толстой плиты (полки), на которой расположены нужной формы архитектурные обломы. На базе устанавливают тело колонны, завершающееся капителью. Иногда колонны утоняются не только к верху, но и к низу, т.е. имеют двойное утонение. У таких колонн наибольшая толщина находится на 1/3 расстояния от низа колонны.

Антаблемент представляет собой верхнюю, поддерживаемую часть архитектурного ордера, состоящую из трех частей: 1) архитрава, представляющего собой балку, являющуюся основной несущей частью и состоящую из каменных блоков, которые перекрывают пролет между колоннами; 2) фриза, под которым понимается среднее членение антаблемента, представляющее собой широкий пояс; 3) и карниза (верхней части антаблемента) [2, с. 4]. 
Итак, в теории ордеров существуют полные и неполные ордера, более того, они бывают простыми и сложными. К простым относится тосканский и дорический, к сложным - ионический, и коринфский.

Как указывают исследователи, первоначально дорический ордер возник на островах и побережьях Эгейского моря и получил наибольшее распространение в Западной части Греческого мира. Свое название он получил от дорийских племен, населявших территорию Греции [1, с. 8]. Дорический ордер среди прочих наиболее прост. Он весьма массивный и способен выдерживать значительные напряжения, которые могут возникнуть в каменной конструкции. Более того, колонна греческого дорического ордера не имела базы и устанавливалась сразу на стилобат, представляющую собой верхнюю площадку стереобата. Полагают, что греческий дорический ордер олицетворяет мужество и силу. Строгость и простота, вместе с тем пластичность форм данного ордера достигли своего высшего выражения в облике Парфенона.

Ионический ордер берет свое название от страны Ионии, расположенной на побережье Малой Азии. Данный ордер довольно лёгкий и не такой массивный как предыдущий. Его сопоставляли с изяществом и грацией женщины, а завитки венчающей части этого ордера - капители - сравнивали с искусно убранными женскими волосами. Греки, возводя храмы ионического ордера, заимствовали пропорции женской фигуры. Они приняли толщину колонны, равную одной восьмой части её высоты, за счёт чего она приобрела большую высоту и стройность [1, с. 9]. Следует отметить, что под основанием колонны этого ордера уже устанавливали базу, покоящуюся на стилобате. База делает колонну более изящной и пластичной. В качестве примера ионического ордера можно привести ордер Эрехтейона. Это храм, который расположен на афинском акрополе. В нем можно увидеть два варианта антаблемента: с фризом (восточный и северный портик) и без него (в портике Кариатид).

Корфинский ордер возник позже других и во многом напоминал ионический. Этот ордер ещё более сложный и богато украшен. Его характерной чертой 
являлась высокая капитель, декорированная рельефными изображениями листьев анакфа - ядовитого растения. Самое большое изображение аканфа, известное в истории и археологии - это каменный столп в Дельфах.

Итак, каждый вид архитектурного ордера обладает определенной соразмерностью между частями и элементами ордера. Каждому ордеру свойственны свои пропорции. Интересно отметить, что греки очень умело использовали ордер в архитектурных композициях. Когда нужно было придать архитектурному сооружению характер силы и мужества, они применяли дорический ордер. Ионический ордер использовали, когда хотели создать изящность, нежность или грациозность. Величие, торжественность и богатство выражалось коринфским ордеpom.

Итак, попытки использования античных ордеров имеют многовековую традицию. На протяжении нескольких тысячелетий ордера неоднократно возрождались и исчезали со сцены архитектурного действа. Постмодерн - это далеко не последнее звено в цепи таких возрождений. В будущем непременно будут новые попытки переосмысления античного наследия, появятся новые формы и стили. Ордера всегда были и будут «вечным» объектом пристального внимания и изучения как опытных архитекторов профессионалов, так и вступающих на путь профессии молодых людей.

\section{Сиисок литературы}

1. Гоголева Н.А. Ордера архитектуры / Н.А. Гоголева; Нижегор. гос. архитектур.-строит. ун-т. - Н. Новгород: ННГАСУ, 2015. - 117 с.

2. Заковоротная Т.А. Архитектурные ордера / Т.А. Заковоротная, В.И. Мартынова, Н.В. Фурман. - Саратов: СГТУ, 2006. - 76 с.

3. Избранные научные труды / С.Ф. Издательско-полиграфический центр СОИГСИ. Северо-Осетинская организация Союза архитекторов России. - Владикавказ, 2014. - 162 с.

Залесов Иван Нестерович - преподаватель ГПОАУ «Амурский колледж строительства и жилищно-коммунального хозяйства», Россия, Благовещенск. 
Zalesov Ivan Nesterovich - teacher SPEAI of the Amur Region «Amur College of Construction and Housing and Public Utilities», Russia, Blagoveshchensk. 